\title{
Carbon dioxide capture and utilization in petrochemical industry: potentials and challenges
}

\author{
Maryam Takht Ravanchi $\cdot$ Saeed Sahebdelfar
}

Received: 7 February 2014 / Accepted: 4 March 2014/Published online: 23 March 2014

(c) The Author(s) 2014. This article is published with open access at Springerlink.com

\begin{abstract}
The reduction of greenhouse gas emissions is an ever-increasing challenge for production units and power plants in view of the global warming concerns. Carbon dioxide capturing from petrochemical process streams and flares has been recognized as one of the several strategies necessary for mitigating the emission of greenhouse gases into the atmosphere. To keep greenhouse gases at manageable levels, large decrease in $\mathrm{CO}_{2}$ emissions through separation and utilization will be required. Furthermore, carbon dioxide emission potential will become an important factor in technology selection when cost of carbon dioxide emissions is set to be included in the processing cost. This article reviews the potential $\mathrm{CO}_{2}$ separation technologies and its recycling via chemical fixation as bulk chemical products in petrochemical industry. Various separation techniques, such as absorption, adsorption, membrane separation and cryogenic, and utilization processes, such as conversion to carbon monoxide, oxidative dehydrogenation, hydrogenation and polymerization are thoroughly discussed. The technological challenges and recent developments and achievements are also presented.
\end{abstract}

Keywords Carbon dioxide - Greenhouse gas (GHG) . Carbon capture and utilization (CCU) - Catalytic conversion $\cdot \mathrm{C}_{1}$ chemistry $\cdot$ Petrochemical industry

M. Takht Ravanchi $(\bowtie) \cdot$ S. Sahebdelfar

Catalyst Research Group, Petrochemical Research and

Technology Company, National Petrochemical Company,

No. 27, Sarv Alley, Shirazi-south, Mollasadra,

P.O. Box 14358-84711, Tehran, Iran

e-mail: m.ravanchi@npc-rt.ir; maryamravanchi@gmail.com

\section{Introduction}

Environmental issues due to emissions of greenhouse gases (GHGs) have become worldwide problems. Studies have shown that increased GHG levels in atmosphere cause global warming. Carbon dioxide $\left(\mathrm{CO}_{2}\right)$, methane $\left(\mathrm{CH}_{4}\right)$, nitrous oxide $\left(\mathrm{N}_{2} \mathrm{O}\right)$ and fluorinated gases (HFC, $\mathrm{PFC}, \mathrm{SF}_{6}$ ) are greenhouse gases among which carbon dioxide makes up a high proportion with respect to its amount present in the atmosphere (Fig. 1). Going by the prediction of Intergovernmental Panel on Climate Change (IPCC), by year 2100 , the atmosphere may contain up to $570 \mathrm{ppm}$ of $\mathrm{CO}_{2}$, causing a rise in mean global temperature of around $1.9^{\circ} \mathrm{C}$ and an increase in mean sea level of $3.8 \mathrm{~m} \mathrm{[1].}$

The proportion of greenhouse gases has increased significantly since the Industrial Revolution (about 1750), and global carbon dioxide $\left(\mathrm{CO}_{2}\right)$ concentration has risen by $37 \%$.

At present, it is accepted that the increase of GHG concentration in atmosphere is attributed to human activities. Greenhouse gas emissions are produced as the byproducts of various non-energy-related industrial activities. Industrial processes can chemically transform raw materials, which often release waste gases such as $\mathrm{CO}_{2}$. The processes include production of iron, steel, metallurgical coke, cement, lime, carbonate consuming processes (e.g., flux stone, flue gas desulfurization, and glass manufacturing), ammonia and urea, petrochemical, aluminum, soda ash, titanium dioxide, ferroalloy and glass. The production of some petrochemicals results in the release of small amounts of $\mathrm{CO}_{2}$ emissions. Petrochemicals are chemicals isolated or derived from petroleum or natural gas. The chemical and petrochemical industry accounts for $30 \%$ of global industrial energy use and $16 \%$ of direct $\mathrm{CO}_{2}$ 


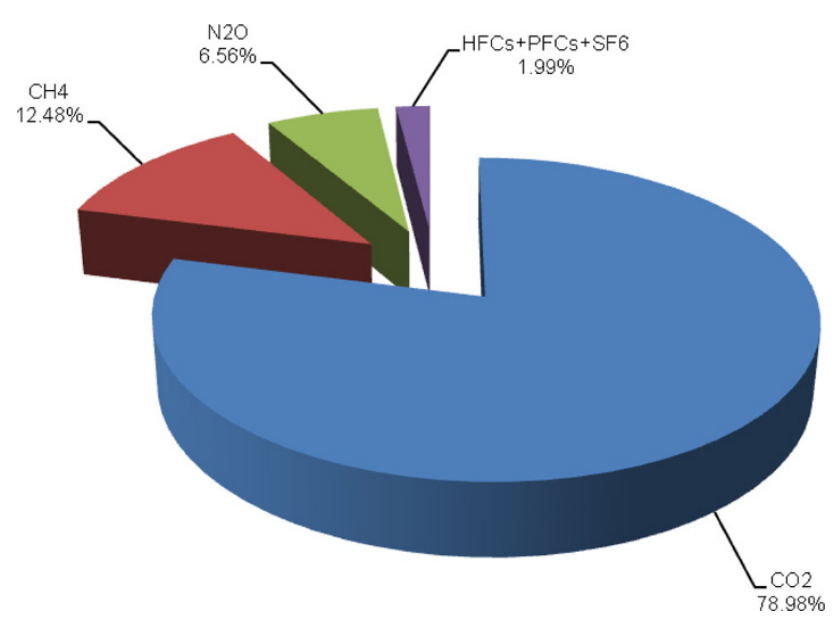

Fig. 1 Greenhouse gas emission in 2011 [1]

emissions. More than half of the energy demand is for feedstock use, which cannot be reduced through energy efficiency measures $[2,3]$.

The public concern about the climate change due to the greenhouse gas emissions to atmosphere led to the United Nation Framework Convention on Climate Change (UNFCCC) in 1992. The main objective of this meeting was to discuss methods for stabilization of GHG concentrations in the atmosphere at a level that the anthropogenic emissions could not interfere with the climate system. The stabilization of GHG concentrations in atmosphere can be achieved by three approaches:

- Reducing energy intensity

- Reducing carbon intensity (by use of carbon-free fuels)

- Enhancing the sequestration of $\mathrm{CO}_{2}$

Carbon dioxide capture and sequestration (CCS) can significantly reduce emissions from $\mathrm{CO}_{2}$ sources as well as certain industry types such as ethanol and natural gas processing plants. CCS methodologies for industrial and energy-related sources comprise three steps: $\mathrm{CO}_{2}$ capture, $\mathrm{CO}_{2}$ transportation and $\mathrm{CO}_{2}$ utilization.

There are various petrochemical units that produce carbon dioxide with high purity as a by-product such as ethylene oxide and ammonia processes. Flaring is another main emission source of this greenhouse gas in petrochemical industry. In petrochemical industry, hydrocarbon wastes can be used as fuel and recycled. Therefore, the main waste products are water and $\mathrm{CO}_{2}$. Carbon dioxide is produced in petrochemical process streams mostly by reactions with oxygenates (mainly oxygen as in oxidation of ethylene and water as in water-gas shift reaction). In fact, ethylene oxide and ammonia processes produce carbon dioxide with high purity as a by-product. However, most of the carbon dioxide in petrochemical industry is emitted in the flue gas as a result of burning fuel oil and fuel gas [4].

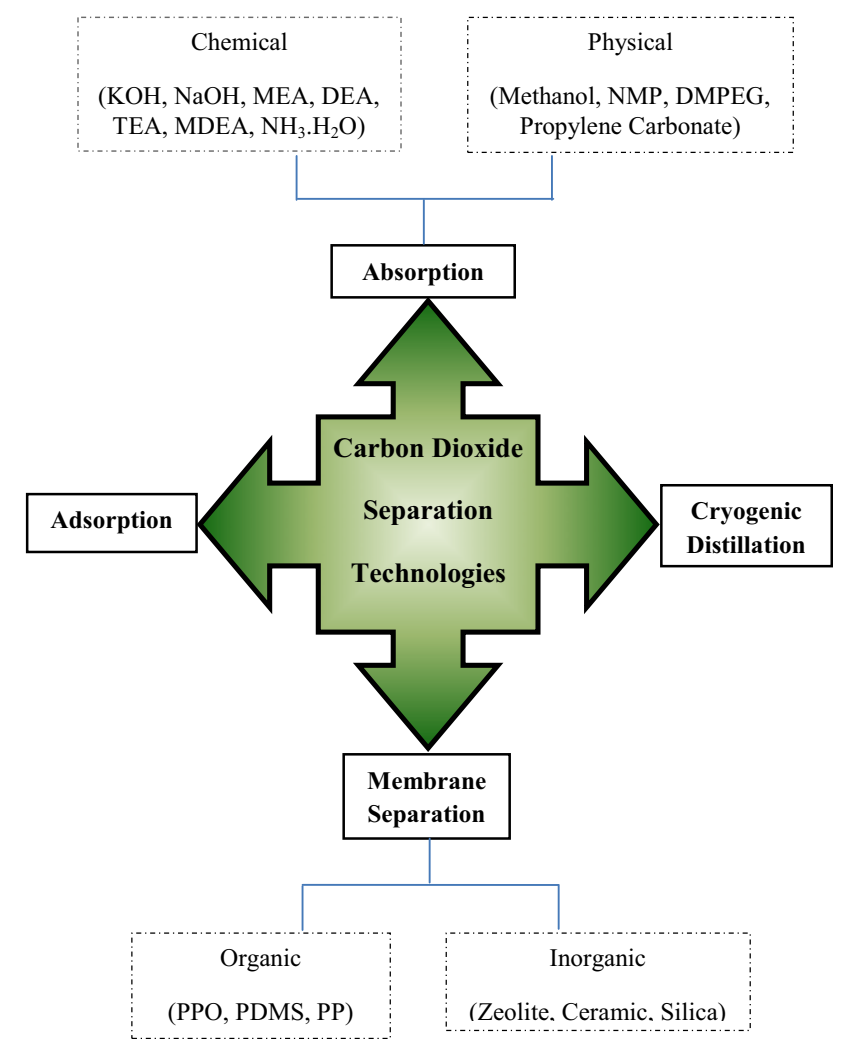

Fig. 2 Available technologies for $\mathrm{CO}_{2}$ separation

In literature, there are some valuable reviews published in different aspects of CCS. For instance, in the field of $\mathrm{CO}_{2}$ capture Granite and O`Brien [5]; Stewart and Hessami [6]; Olajire [7]; Pires et al. [8]; Takht Ravanchi et al. [9]; Wang et al. [10]; Kargari and Takht Ravanchi [11]; Zhao et al. [12]; Songolzadeh et al. [13]; and in the field of $\mathrm{CO}_{2}$ utilization Wang and Zhu [14]; Song [15]; He et al. [16]; Havran et al. [17] are worth mentioning. Due to the absence of a systematic and detailed review on $\mathrm{CO}_{2}$ separation and fixation in petrochemical industry, the present research focused on this goal.

\section{$\mathrm{CO}_{2}$ separation techniques}

Capturing and separation of $\mathrm{CO}_{2}$ from petrochemical gas streams are essential parameters for the carbon management for $\mathrm{CO}_{2}$ sequestration from environment.

Generally, $\mathrm{CO}_{2}$ separation contributes to $70-80 \%$ of the overall CCS cost [4]. Hence, reducing separation cost is the most important issue for CCS process. In this section, common technologies of $\mathrm{CO}_{2}$ separation from a flue gas are focused.

A wide range of technologies based on physical and chemical processes currently exist for $\mathrm{CO}_{2}$ separation from a gas stream categorized as absorption, adsorption, 
membrane separation and cryogenics (Fig. 2). The choice of a suitable technology depends on the characteristics of gas stream.

Biological and hybrid processes and chemical looping combustion (CLC) are other $\mathrm{CO}_{2}$ separation techniques which are not considered in this review. In biological processes, trees or microalgae can be used for $\mathrm{CO}_{2}$ capture $[6,18]$. Chemical looping combustion, proposed by Richter and Knoche [19], divides combustion into intermediate oxidation and reduction reactions that are performed separately with a solid oxygen carrier circulating between the separated sections. Hybrid systems can be based on membrane associated with cryogenic distillation or solvent absorption.

\section{Absorption}

\section{Chemical absorption}

The basic principle of chemical absorption is neutralization reaction in which absorbent react with $\mathrm{CO}_{2}$ in the flue gas. The ideal chemical absorbent must have below specifications [20]:

- High reactivity with respect to $\mathrm{CO}_{2}$-which would reduce height requirements for the absorber and/or reduce solvent circulation flow rates.

- Low regeneration cost requirements-based on a low heat of reaction with $\mathrm{CO}_{2}$.

- High absorption capacity-which directly influences solvent circulation flow rate requirements.

- High thermal stability and reduced solvent degradation-reduced solvent waste due to thermal and chemical degradation.

- Low environmental impact.

- Low solvent costs-should be easy and cheap to produce.

Strong and weak alkaline solutions are commonly used absorbents. $\mathrm{KOH}$ and $\mathrm{NaOH}$ are examples of strong alkaline solutions, and alcohol amines (such as MEA, DEA, TEA and MDEA) and aqueous ammonia $\left(\mathrm{NH}_{3} \cdot \mathrm{H}_{2} \mathrm{O}\right)$ are examples of weak alkaline solutions.

The applicability of strong alkaline solution is limited due to its strong corrosion to equipment. The alcohol amines usually suffer from the disadvantage of high energy requirement for regeneration, easy oxidation/degradation by $\mathrm{SO}_{2}$ and $\mathrm{O}_{2}$ in flue gas and system corrosion [21, 22]. Aqueous ammonia has the advantage of high-absorption efficiency, high-absorption capacity, low-energy requirement for absorbent regeneration and wide distribution of resources. In Table 1, advantages and disadvantages of chemical absorption by different alkaline solutions are categorized.
Table 1 Advantages and disadvantages of alkaline approaches for $\mathrm{CO}_{2}$ capture

\begin{tabular}{|c|c|c|}
\hline Process & Advantage & Disadvantage \\
\hline $\begin{array}{l}\text { Strong alkaline/alkaline } \\
\text { metal solution }(\mathrm{KOH}, \\
\mathrm{NaOH} \text { solution) }\end{array}$ & $\begin{array}{l}\text { Fast reaction rate } \\
\text { Large absorption } \\
\text { capability } \\
\text { High absorption } \\
\text { efficiency }\end{array}$ & $\begin{array}{l}\text { Cost of absorbent } \\
\text { Strong corrosion } \\
\text { to equipment } \\
\text { Product treatment } \\
\text { and disposal }\end{array}$ \\
\hline $\begin{array}{l}\text { Weak alkaline } \\
\left(\mathrm{NH}_{3} \cdot \mathrm{H}_{2} \mathrm{O}\right)\end{array}$ & $\begin{array}{l}\text { Large absorption } \\
\text { capability and high } \\
\text { loading capacity } \\
\text { Low-energy } \\
\text { requirement for } \\
\text { absorbent } \\
\text { regeneration } \\
\text { Utilization of } \\
\text { products as fertilizer } \\
\text { Wide distribution of } \\
\text { absorbent }\end{array}$ & $\begin{array}{l}\text { Easy to volatilize } \\
\text { and leak } \\
\text { Thermal } \\
\text { instability of } \\
\text { products } \\
\text { Corrosion to } \\
\text { equipment }\end{array}$ \\
\hline $\begin{array}{l}\text { Aqueous ammines } \\
\text { (MEA, DEA, TEA, } \\
\text { MDEA) }\end{array}$ & $\begin{array}{l}\text { Less volatility } \\
\text { Good stability of } \\
\text { absorbent } \\
\text { Enhancement role } \\
\text { used as additive }\end{array}$ & $\begin{array}{l}\text { Absorption } \\
\text { efficiency } \\
\text { High-energy } \\
\text { consumption for } \\
\text { regeneration } \\
\text { Easy degradation } \\
\text { by } \mathrm{SO}_{2} \text { and } \mathrm{O}_{2} \\
\text { in flue gas } \\
\text { Resulting in } \\
\text { system } \\
\text { corrosion }\end{array}$ \\
\hline
\end{tabular}

Between several chemical absorption processes, MEA would be the first to be available for immediate industrial application. Development of new solvents has achieved some progress such as ammonia [23], piperazine promoted $\mathrm{K}_{2} \mathrm{CO}_{3}$ [24], and concentrated aqueous piperazine [25].

\section{Physical absorption}

Physical absorption takes place at high $\mathrm{CO}_{2}$ partial pressures. This process is not economical for streams with $\mathrm{CO}_{2}$ partial pressures lower than 15 vol\%.

In physical absorption, organic solvent is used to physically, rather than chemically, absorb $\mathrm{CO}_{2}$. In this process, $\mathrm{CO}_{2}$ removal is based on its solubility within the solvents which depends on the partial pressure and temperature of the feed gas. Higher $\mathrm{CO}_{2}$ partial pressure and lower temperature favor the solubility of $\mathrm{CO}_{2}$ in absorbent. The solvents are regenerated by increasing temperature or decreasing pressure. In comparison with chemical solvents, the interaction between $\mathrm{CO}_{2}$ and absorbent is weak.

Physical absorption process and related solvents for $\mathrm{CO}_{2}$ removal are commercially available. Selexol process is based on dimethyl ethers of polyethylene glycol (DMPEG), 
a Union Carbide liquid glycol-based solvent, and has been used since 1969. Glycol is effective for $\mathrm{CO}_{2}$ capturing at high concentration. Rectisol process is based on low temperature methanol (cold methanol). Glycol carbonate is another interesting solvent because of its high selectivity for $\mathrm{CO}_{2}$ but it has relatively low capacity. Propylene carbonate (FLUOR process) and $N$-methyl-2-pyrrolidone (NMP-Purisol) are other physical solvents [26].

Some $\mathrm{CO}_{2}$ capture applications benefit from a mixture of physical and chemical solvents. The most commonly used examples are Sulfinol, a mixture of the physical solvent sulfolane and the amines such as diisopropyl amine (DIPA) or methyl diethanolamine (MDEA); and Amisol, a mixture of methanol and secondary amines. These hybrid solvents attempt to exploit the positive qualities of each constituent under special conditions.

\section{Membrane separation}

Membrane separation technology is a low cost process when high purity gas streams are not fundamental [27]. Membranes can separate carbon dioxide from a gas stream by size exclusion or by chemical affinity. Chemical affinity membranes are often impregnated with a scrubbing solution or chemical functional group (e.g., amine) selective for carbon dioxide. The scrubbing solutions, as well as functional groups on the surface of sorbents, are discussed in the critical review papers [28, 29]. A large body of research has been conducted on the properties of carbon dioxide selective membranes based on inorganic materials such as zeolites, alumina, carbon, and silica. Researchers proposed the separation of carbon dioxide from flue gases by multiwalled carbon nano-tube membranes [5]. Substantial advances in the selectivity, permeability, and chemical stability of inorganic membranes are needed for successful application to gas mixtures.

Membrane process has several advantages [30]:

- Higher separation energy efficiency relative to equilibrium-based processes.

- No waste streams production.

- Existence of commercial references (e.g., $\mathrm{CO}_{2}$ separation from natural gas).

- No regeneration energy required.

- High packing density which requires small installations.

- Increasing mass transfer area in a given volume.

Its major drawbacks can be categorized as below:

- The treatment of an enormous flow rate of $\mathrm{CO}_{2}$ containing gas requires a very large membrane area and increases the cost of this technology.
- The need of very large, expensive and energy consuming compression equipment.

Organic (polymeric) and inorganic (zeolite, ceramic and silica) membranes are of particular interest in $\mathrm{CO}_{2}$ separation. Polymeric membranes separate gases based on solution-diffusion mechanism. Low cost, high separation performance, ease of synthesis and mechanical stability are their advantages [31, 32]. An important limitation of polymeric membrane is its application for a high-temperature gas stream as it cannot be applied without cooling of the gas stream in order not to destroy the membrane.

It was recently demonstrated that a zeolitic imidazolate framework with high thermal (up to $390{ }^{\circ} \mathrm{C}$ ) and chemical stability under refluxing organic and aqueous media shows exceptional selectivity for $\mathrm{CO}_{2}$ capture from $\mathrm{CO}_{2} / \mathrm{CO}$ mixtures with an extraordinary capacity for storing $\mathrm{CO}_{2}$.

\section{Adsorption}

Adsorption is also considered a feasible process for $\mathrm{CO}_{2}$ capture at an industrial scale. It is a selective process in which molecules contained in liquid or gaseous mixtures adhere on a solid surface, the adsorbent. These molecules, even in small concentrations in the streams, can be captured by these selective materials. The properties of the adsorbed particles (molecular size, molecular weight and polarity) and the adsorbent surface (polarity, pore size and spacing) determine the adsorption quality. As adsorption is an exothermic process, the regeneration of the adsorbents through desorption can be performed by rising the temperature. However, adsorption presents lower energy requirements and avoids the shortcomings when compared to absorption [33]. Adsorption can be either physical (physisorption) or chemical (chemisorption).

Several adsorbents have been proposed for $\mathrm{CO}_{2}$ capture, including carbon fiber monolithic adsorbents [34], activated carbon fiber-phenolic resin composites [35], melamine-formaldehyde highly porous adsorbents [36], amine immobilized adsorbents [37], red mud [38], steam-activated anthracite [39], activated carbon [40], lithium zirconate [41], lithium silicate [42, 43], alumina, metallic oxides and zeolites [44] among others [45, 46]. Sjostrom and Krutka [47] compared several adsorbents and concluded that carbon-based materials present excellent stability, while zeolites work well under dry conditions.

In the industrial context, a continuous $\mathrm{CO}_{2}$ capture process is preferred while the technologies often studied are the cyclic processes. These adsorption processes can be grouped into two types, according to the way in which the adsorbent is exchanged between the adsorption and desorption steps: by changing the pressure or the temperature. In pressure swing adsorption (PSA), the adsorption is 
performed at pressures higher than atmospheric. Desorption occurs at atmospheric pressure. However, a vacuum desorption pressure can be applied and, for commercial adsorbent $13 \mathrm{X}$, the costs of $\mathrm{CO}_{2}$ capture are comparable with the cost of MEA absorption [48]. The operation with an adsorbent with higher adsorption capacity and higher selectivity to $\mathrm{CO}_{2}$ would increase the profitability of PSA. The vacuum swing adsorption (VSA) operates at nearambient temperature and pressures and desorption is performed at lower pressure. It is a promising technology due to the relatively low power consumption and ease of operation.

$\mathrm{CO}_{2}$ containing gas streams to be treated by adsorption must have high $\mathrm{CO}_{2}$ concentrations because of the low selectivity of the most available adsorbents.

\section{Cryogenic distillation}

$\mathrm{CO}_{2}$ cryogenic distillation involves separation of gas mixture by fractional condensation and distillation at low temperature. Cryogenic temperatures are obtained by a closed-cycle operated refrigeration system consisting of a compressor, a Joule-Thompson valve (JTV), multi-stage heat exchangers and expanders.

Cryogenic distillation is a commercial process commonly used to liquefy and purify $\mathrm{CO}_{2}$ from high purity sources $(>90 \%)$. It involves cooling the gas to a very low temperature (lower than $-73.3{ }^{\circ} \mathrm{C}$ ) so that $\mathrm{CO}_{2}$ can freeze out/liquefied and separated.

The CryoCell ${ }^{\circledR}$ technology developed by Cool Energy Ltd (Australia) uses a cryogenic process for $\mathrm{CO}_{2}$ removal. This technology eliminates water consumption, uses of chemicals and corrosion-related issues.

\section{Advantages and constraints}

In the field of carbon dioxide capture and utilization for petrochemical industry, the separation process has high importance as it should provide $\mathrm{CO}_{2}$ within the specified purity required and with reasonable costs. Each of the above explained separation techniques has advantages and constraints. $\mathrm{CO}_{2}$ concentration, temperature and pressure of flue gas streams are main operating parameters based on which suitable separation process can be selected.

Chemical absorption method has many obvious advantages such as high efficiency, high absorption capacity, low cost and mature technology. These solvents are usually preferred to physical ones. Physical solvents required low regeneration energy, but they have low absorption capacity and selectivity for $\mathrm{CO}_{2}$ separation. Physical absorption is not economical for gas streams with $\mathrm{CO}_{2}$ concentration lower than $15 \mathrm{vol} \%$. Research efforts should be directed toward developing better solvents. Future progress in solvents should be:

- to reduce energy consumption;

- to avoid damage to environment and human being (when it is vented with treated gas);

- acceptable solvent degradation and corrosion to the packed column.

More important is to combine all these in one solvent. For gas streams with high temperature (about $373 \mathrm{~K}$ ), low pressure and low $\mathrm{CO}_{2}$ concentration (1 atm and 10-15\% mol), bulk absorption process may be the best suitable process for $\mathrm{CO}_{2}$ separation.

Adsorption is suitable for separating $\mathrm{CO}_{2}$ from low flow rate stream. Although, chemical adsorbents have high capacity and selectivity, but their regeneration is difficult. Physical adsorption is the most suitable for $\mathrm{CO}_{2}$ capture at high pressures and low temperatures.

Since the pressure drop is driving force for membrane process, the gas stream must be compressed. Since compressing is very difficult and expensive, membrane separation is suitable for high pressure stream with high concentration ( $>10$ vol\%). Inorganic membranes have high thermal and chemical stability but their selectivity is lower than polymeric membranes. Polymeric membranes are very selective for $\mathrm{CO}_{2}$ separation but they have low thermal stability. Glassy polymeric membranes have higher selectivity, while the rubbery polymeric membranes have higher thermal stability.

Membrane processes and cryogenic distillation are efficient for gas streams with high $\mathrm{CO}_{2}$ concentration. Major disadvantage of cryogenic distillation is the large amount of energy required to provide the refrigeration.

Consequently, for capture from flue gases of petrochemical plants, adsorption and absorption appear to be the choice at least in short- and medium-term perspective.

\section{$\mathrm{CO}_{2}$ utilization}

The disposal or utilization of the captured $\mathrm{CO}_{2}$ is another problem for adequate reduction of $\mathrm{CO}_{2}$ emissions. A potential and attractive route to use the captured $\mathrm{CO}_{2}$ is its fixation as valuable petrochemical commodities or fuels. Figure 3 presents some of the current and potential utilization routes for $\mathrm{CO}_{2}$.

Chemical fixation of carbon dioxide

Carbon dioxide, a cheap and abundant C-containing raw material, is interesting as substrate, solvent, reactant, and extracting agent. $\mathrm{CO}_{2}$ is a potential $\mathrm{C}_{1}$ building block for $\mathrm{C}-\mathrm{C}$ chains or as competitive source of $\mathrm{C}$ in chemical 


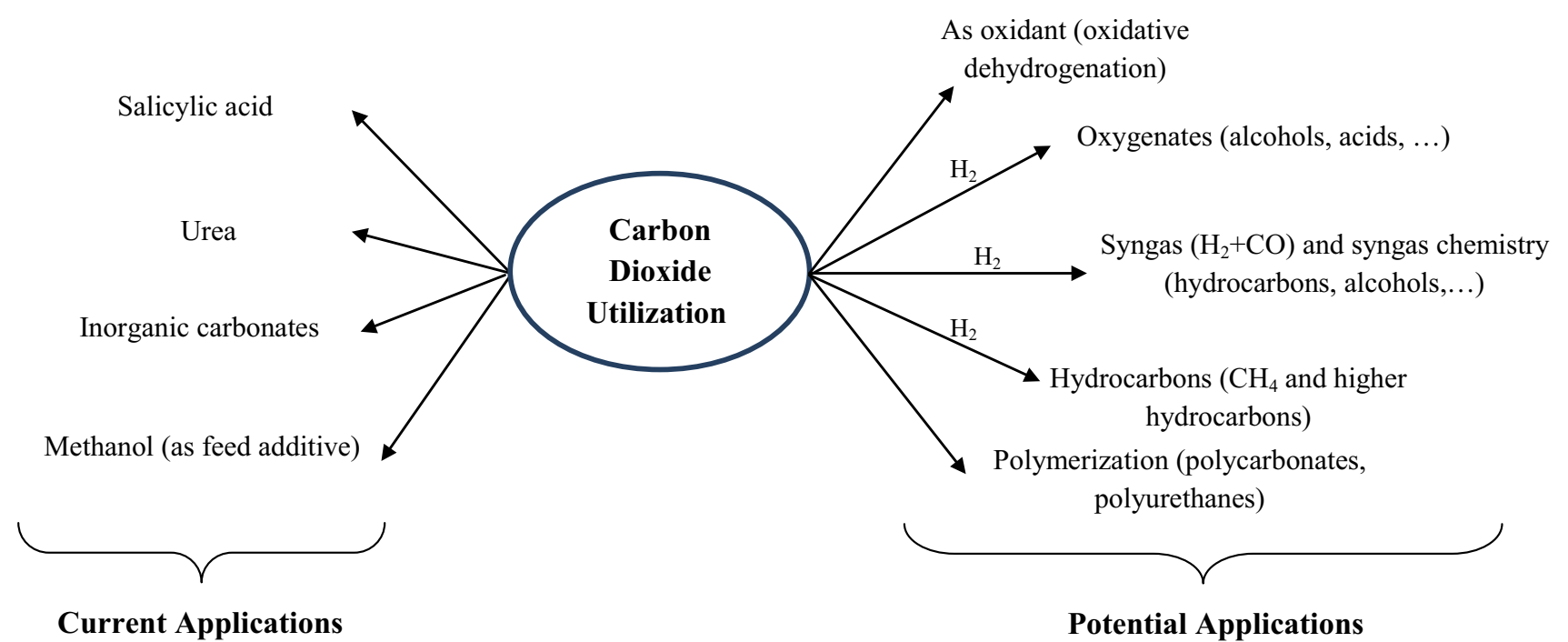

Fig. 3 Current and potential applications of $\mathrm{CO}_{2}$ utilization

Table 2 Main uses of carbon dioxide in the chemical industry in Mtpy [55]

\begin{tabular}{llc}
\hline Process & Present & 2016 forecast \\
\hline Urea & 114 & 132 \\
Inorganic carbonates & ca. 50 & 70 \\
Methanol & 8 & 10 \\
Total & 172 & 217 \\
\hline
\end{tabular}

industry and appears very attractive, although the molecule is rather inert and its reactions are energetically highly unfavorable [49]. There are several good recent review articles on $\mathrm{CO}_{2}$ chemical fixation [17, 50-54].

The total amount of carbon dioxide used in industry is approximately $200 \times 10^{6}$ metric tons per year. Major industrial processes that utilize $\mathrm{CO}_{2}$ as a raw material are listed in Table 2. Its utilization as a technological fluid, where carbon dioxide is not chemically converted and thus can be recovered at the end, is estimated at $30 \times 10^{6}$ metric tons per year [55]. The generation of energy used for $\mathrm{CO}_{2}$ transformation, if based on hydrocarbon raw materials, still produces large amounts of $\mathrm{CO}_{2}$. In addition, the resulting organic chemicals from $\mathrm{CO}_{2}$ release carbon dioxide at the end of their use. However, despite the fact that, currently, the usage of $\mathrm{CO}_{2}$ in the chemical industry cannot reduce significantly the global $\mathrm{CO}_{2}$ levels, it is believed that the full potential of the fixation of $\mathrm{CO}_{2}$ into value-added products has not yet been completely explored. The direct use of non-hydrocarbon based energy sources for reduction of $\mathrm{CO}_{2}$ would change the above perspective and allow recycling of carbon dioxide via chemicals and liquid fuels. Thus, the further development of industrial processes, that are utilizing $\mathrm{CO}_{2}$ for highdemand products, is of importance.
The scale of fixation for a specific product is an important parameter. Many fine chemicals or those of pharmaceutical interest produced by incorporation of $\mathrm{CO}_{2}$ have only a limited demand worldwide (a few to a hundred ton annually). Regarding the order of magnitude of carbon dioxide emission problem (over $35 \mathrm{Gt}$ annually), many of the claimed $\mathrm{CO}_{2}$ reduction processes can be described as only a small step forward to resolve the problem and will not have a significant impact on the overall carbon emission problem. Those $\mathrm{CO}_{2}$-fixing reactions that are feasible and show a significant bearing on overall worldwide carbon emissions are required on a very large scale. Typical examples include the conversion of $\mathrm{CO}_{2}$ into fuels and polymeric/construction materials, which are in significant demand [54].

To date, only a few compounds have been successfully synthesized from $\mathrm{CO}_{2}$ using heterogeneous catalytic routes, since most industrial processes utilize the more reactive but highly toxic carbon monoxide $(\mathrm{CO})$ as a building block to produce higher chain hydrocarbons and liquid fuels. Processes for potential future utilization of $\mathrm{CO}_{2}$ that have not yet been scaled up for commercialization are dependent on the development of new catalytic systems [17].

The source of energy supply should come from either renewable (solar, wind, hydro, ground heat, biomass, etc.) or integrated heat-management systems (nuclear plants or waste heat from industrial processes). Equally, the source of chemical reagents to couple with carbon dioxide should be carefully considered without any net enhancement in overall carbon emissions (to avoid a scenario that the $\mathrm{CO}_{2}$ emission for the production of the coupling reagent is more than it captures). By taking thermodynamic limitations and the total carbon emissions of an overall process into 
account, many previously reported methods for carbon dioxide conversion may not be able to provide a practical way to globally reduce $\mathrm{CO}_{2}$ emissions, although some of these reactions are of academic interest [54].

\section{Chemistry and thermodynamic aspects}

Being the most oxidized state of carbon, $\mathrm{CO}_{2}$ as a raw material is in its lowest energy level, thus posing a major hindrance in establishing industrial processes. In other words, a large energy input is required to transform $\mathrm{CO}_{2}$. There are four main methodologies to transform $\mathrm{CO}_{2}$ into useful chemicals [52]:

- To use high-energy starting materials such as hydrogen, unsaturated compounds, small-membered ring compounds, and organometallics.

- To choose oxidized low-energy synthetic targets such as organic carbonates.

- To shift the equilibrium to the product side by removing a particular compound.

- To supply physical energy such as light or electricity.

Selecting appropriate reactions can lead to a negative Gibbs free energy of the reaction.

A widely accepted idea is that $\mathrm{CO}_{2}$ is so thermodynamically and kinetically stable that it is rarely used to its fullest potential. However, due to the electron deficiency of the carbonyl carbons, $\mathrm{CO}_{2}$ has a strong affinity toward nucleophiles and electron-donating reagents. In other words, $\mathrm{CO}_{2}$ is an "anhydrous carbonic acid", which rapidly reacts with basic compounds [52].

Figure 4 shows the equilibrium conversion and product composition for methanation of carbon dioxide with hydrogen, obtained by constrained Gibbs free energy minimization method. This reaction is among thermodynamically favored reactions of $\mathrm{CO}_{2}$. The equilibrium conversion is fairly high in the range of interest $\left(300-400{ }^{\circ} \mathrm{C}\right)$ with a high selectivity to methane. However, as the temperature increases, the selectivity decreases and shifts to $\mathrm{CO}$, indicating that the reverse reaction (dry reforming of methane) is favored. As higher organic compounds (hydrocarbons and oxygenates) are thermally unstable, lower temperatures favor higher selectivities to these compounds at the expense of lower reaction rates and $\mathrm{CO}_{2}$ conversions.

\section{Catalysis}

Catalysts play a crucial role in $\mathrm{CO}_{2}$ conversions, and suitable catalysts can realize interactions between $\mathrm{CO}_{2}$ and a substrate on a transition metal center $\mathrm{M}$. $\mathrm{CO}_{2}$ has demonstrated surprising versatility by exhibiting a great variety of coordination and reaction modes in its homo- and polynuclear metal complexes. Most catalytic reactions involving $\mathrm{CO}_{2}$ activation proceed via formal insertion of $\mathrm{CO}_{2}$ into highly reactive $\mathrm{M}-\mathrm{X}$ bonds with the formation of new $\mathrm{C}-\mathrm{X}$ bonds. Coordinated $\mathrm{CO}_{2}$ as in stable complexes is not necessarily required. Reactions are generally initiated by nucleophilic attack of $\mathrm{X}$ at the Lewis acidic $\mathrm{C}$ atom of $\mathrm{CO}_{2}$ [49].

The conversion of carbon dioxide can be accomplished by homogeneous, heterogeneous and biological catalysts. For large-scale implementation, heterogeneous catalysis is preferred.

\section{Homogeneous catalysis}

Homogeneous catalytic processes for conversions of $\mathrm{CO}_{2}$ are, by a large, reactions involving the incorporation of the entire $\mathrm{CO}_{2}$ molecule into the products. These processes can be divided into two main categories: reductions of $\mathrm{CO}_{2}$ that involve formal insertion of $\mathrm{CO}_{2}$ into a bond in another molecule, and those that involve coupling of $\mathrm{CO}_{2}$ with another unsaturated molecule [56].

The mild reaction conditions used in homogeneous hydrogenation of $\mathrm{CO}_{2}$ catalyzed by transition metal complexes allow the partial hydrogenation of $\mathrm{CO}_{2}$ to yield formic acid and derivatives:

$\mathrm{CO}_{2}+\mathrm{H}_{2} \Leftrightarrow \mathrm{HCOOH} \quad \Delta H_{298}^{0}=-32 \mathrm{~kJ} / \mathrm{mol}$

Further reduction of formic acid under homogeneous conditions is more difficult and only very few examples are known reporting formation of methanol and methane catalyzed by $\mathrm{Pd}$ and $\mathrm{Ru}$ complexes in very low yields [57].

\section{Heterogeneous catalysis}

The heterogeneous catalytic conversion of $\mathrm{CO}_{2}$ involves only hydrogenation reactions, with the exception of $\mathrm{CO}_{2}$ reforming of $\mathrm{CH}_{4}$, and occurs at high temperatures. Thus, the product portfolio is much more limited than for homogeneous catalysts:

$$
\begin{array}{ll}
\mathrm{CO}_{2}+\mathrm{H}_{2} \Leftrightarrow \mathrm{CO}+\mathrm{H}_{2} \mathrm{O} & \Delta H_{298}^{0}=+41 \mathrm{~kJ} / \mathrm{mol} \\
\mathrm{CO}_{2}+\mathrm{CH}_{4} \Leftrightarrow 2 \mathrm{CO}+2 \mathrm{H}_{2} & \Delta H_{298}^{0}=+247 \mathrm{~kJ} / \mathrm{mol} \\
\mathrm{CO}_{2}+3 \mathrm{H}_{2} \Leftrightarrow \mathrm{CH}_{3} \mathrm{OH}+\mathrm{H}_{2} \mathrm{O} & \Delta H_{298}^{0}=-49.9 \mathrm{~kJ} / \mathrm{mol} \\
\mathrm{CO}_{2}+4 \mathrm{H}_{2} \Leftrightarrow \mathrm{CH}_{4}+2 \mathrm{H}_{2} \mathrm{O} & \Delta H_{298}^{0}=-113 \mathrm{~kJ} / \mathrm{mol}
\end{array}
$$

Despite the limited diversity, these reactions could be potentially important for chemical utilization of $\mathrm{CO}_{2}$ in the petrochemical industry. As these equations are equilibria, the product yields seldom reach $100 \%$, and, furthermore, the reactions are complicated by several equilibria occurring simultaneously at reaction temperature (see 
(a)

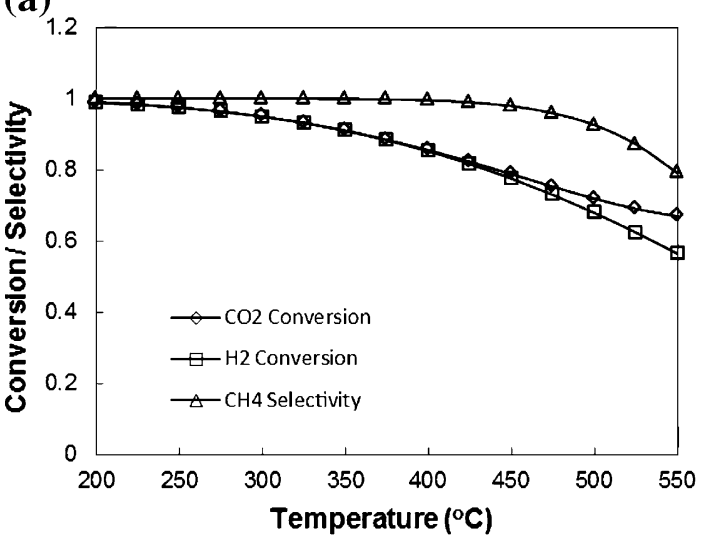

(c)

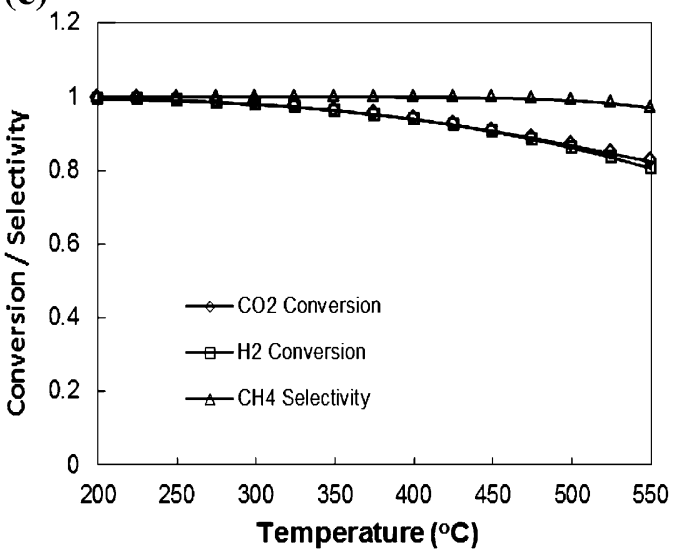

(b)

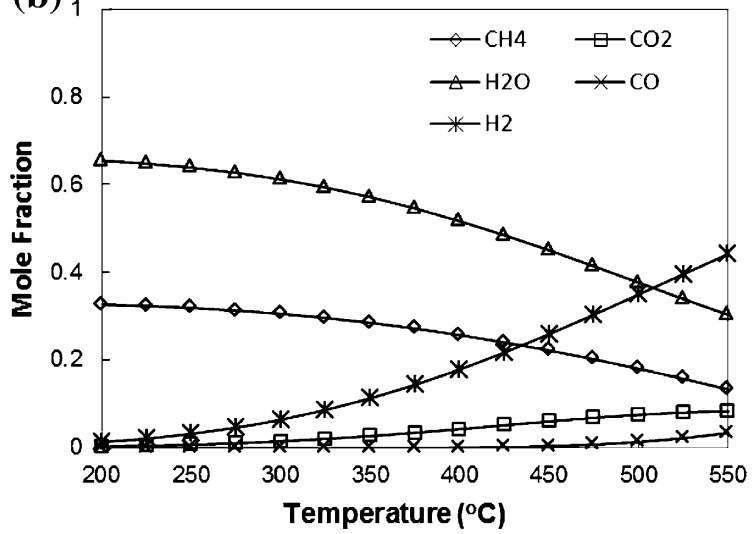

(d)

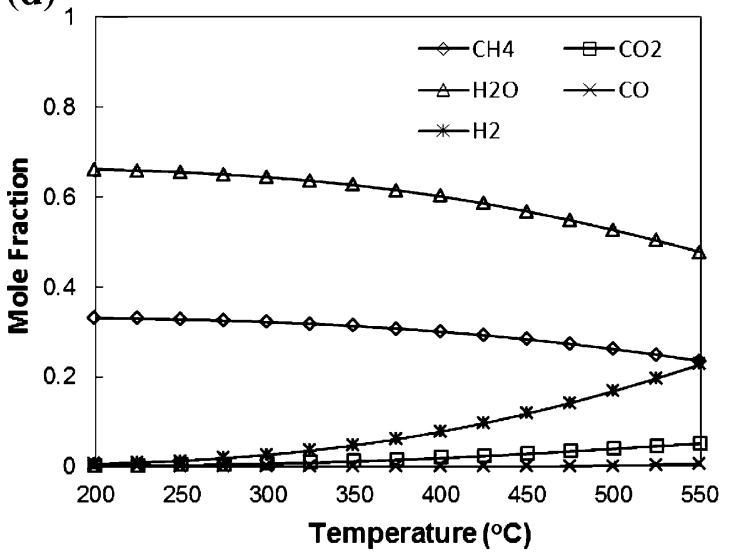

Fig. 4 The effect of temperature on conversions, selectivity and equilibrium product composition at 1 atm (a, b) and 10 atm (c, d) for stoichiometric ratio of $\mathrm{CO}_{2} / \mathrm{H}_{2}$ for methanation

Fig. 4). The art of heterogeneous catalysis is then the ability to minimize these other readily accessible reactions and steer the product formation to that desired.

\section{Electro- and photochemical catalysis}

The electro- and photochemical catalysis is identical in many respects; the major difference is the source of reducing electrons [56]. Electro- and photochemical reductions of $\mathrm{CO}_{2}$ can also be catalyzed by metal complexes.

Methanol or related oxygenates (e.g., formic acid) can be made from $\mathrm{CO}_{2}$ via aqueous electrocatalytic reduction in a "reversed fuel cell" without prior electrolysis of water to hydrogen [57]. The reversed fuel cell accomplishes the electrocatalytic reduction of $\mathrm{CO}_{2}$ outside the potential range of the conventional electrolysis of water. In aqueous solutions, the selectivity depends on the electrode type. The different electrode behavior among metals can be related to their electronic configuration and can be grouped as $s p$ and $d$ metals. Selectivity depends on surface coverage of different reduced species. Higher surface hydrogen species concentration would lead to methane and hydrogen, while more carbon species would lead to $\mathrm{CO}$ and $\mathrm{HCOOH}$. Copper has received much attention because it produces appreciable amounts of hydrocarbons and alcohols from $\mathrm{CO}_{2}$ reduction, although it tends to give mixed product including hydrogen [51].

Photocatalytic reduction of $\mathrm{CO}_{2}$ can be accomplished by suspending photosensitive semiconductor powder in aqueous solutions under irradiation, usually using UV light. Photoreduction of $\mathrm{CO}_{2}$, however, is a completion with $\mathrm{H}_{2}$ formation due to water decomposition, and leads to mixtures of reduced carbon products. Selectivity, therefore, is one major problem of these processes [57].

\section{Potential processes}

For effective reduction of $\mathrm{CO}_{2}$ emissions, only reactions of high scale are of interest. Fortunately, some of heterogeneous catalytic conversions have this potential. Another need is renewable energy (hydrogen) source. 


\section{Conversion to carbon monoxide}

An obvious way to use $\mathrm{CO}_{2}$ in chemical synthesis is its reduction to $\mathrm{CO}$ followed by syngas (a mixture of $\mathrm{H}_{2}, \mathrm{CO}$ and $\mathrm{CO}_{2}$ ) chemistry. This can be performed by hydrogen or methane known as reverse water-gas shift (RWGS) reaction [Eq. (2)] and dry reforming of methane [Eq. (3)], respectively. Both reactions are endothermic and favored at high temperatures and susceptible to coke forming side reactions.

The commercial $\mathrm{Fe}_{2} \mathrm{O}_{3} / \mathrm{Cr}_{2} \mathrm{O}_{3}$, high-temperature shift catalyst might appear a logical candidate for RWGS reaction. However, despite a high initial activity, a low stability for this catalyst has been reported which was attributed to the reduction of $\mathrm{Fe}_{2} \mathrm{O}_{3}$ to $\mathrm{Fe}$ metal and coke formation [58]. $\mathrm{ZnO} / \mathrm{Cr}_{2} \mathrm{O}_{3}$ catalyst, on the other hand, showed both high activity and stability with no coke formation.

The $\mathrm{ZnO}$ showed good specific reaction activity in the temperature range from 400 to $700{ }^{\circ} \mathrm{C}$ but this catalyst was deactivated. All the catalysts except the $\mathrm{ZnO} / \mathrm{Al}_{2} \mathrm{O}_{3}$ $\left(850{ }^{\circ} \mathrm{C}\right)$ showed low stability for the RWGS reaction and was deactivated at the reaction temperature of $600{ }^{\circ} \mathrm{C}$. The $\mathrm{ZnO} / \mathrm{Al}_{2} \mathrm{O}_{3}$ catalyst calcined at $850{ }^{\circ} \mathrm{C}$ was stable during $210 \mathrm{~h}$ under the reaction conditions of $600{ }^{\circ} \mathrm{C}$ and GHSV of $150,000 \mathrm{~h}^{-1}$; showing CO selectivity of $100 \%$ even at the pressure of $5 \mathrm{~atm}$. The high stability of the $\mathrm{ZnO} / \mathrm{Al}_{2} \mathrm{O}_{3}$ catalyst $\left(850^{\circ} \mathrm{C}\right)$ was attributed to the prevention of $\mathrm{ZnO}$ reduction by the formation of $\mathrm{ZnAl}_{2} \mathrm{O}_{4}$ spinel structure. The spinel structure of $\mathrm{ZnAl}_{2} \mathrm{O}_{4}$ phase in the $\mathrm{ZnO} / \mathrm{Al}_{2} \mathrm{O}_{3}$ catalyst calcined at $850{ }^{\circ} \mathrm{C}$ was confirmed by XRD and electron diffraction [59].

Because of low equilibrium conversions, temperatures above $400{ }^{\circ} \mathrm{C}$ should be used. Excess hydrogen can also shift the reaction to completion. Therefore, there is need for the development of novel catalysts (e.g., $\mathrm{Cu} / \mathrm{ZnO}, \mathrm{Pt} / \mathrm{CeO}_{2}$ ) and reaction engineering approaches such as removal of water.

Carbon dioxide or dry reforming of methane has received much attention since 1980s. $\mathrm{CO}_{2}$ reforming of $\mathrm{CH}_{4}$ has great potential economic and environmental benefits. This reaction has the following important advantages:

- The formation of a suitable $\mathrm{H}_{2} / \mathrm{CO}$ ratio for use in valuable oxygenates synthesis.

- The reduction of $\mathrm{CO}_{2}$ and methane emissions; as both gases cause heavy greenhouse effect.

- Better use in chemical energy transmission.

The reaction is more endothermic than steam reforming. Whereas the steam reforming of methane yields syngases with a $\mathrm{H}_{2} / \mathrm{CO}$ ratio of $3, \mathrm{CO}_{2}$ reforming of $\mathrm{CH}_{4}$ results in a ratio of 1 , which may be of interest for some syngas consuming reactions. The equilibrium composition is influenced by the water-gas shift (WGS) reaction. Carbon dioxide reforming needs higher temperatures (with the danger of coke formation); advantageously catalysts may be used ( $\mathrm{Ni}$ on supports such as alumina or $\mathrm{MgO}$ ).

Dry reforming reaction is catalyzed by Group VIII metals, such as $\mathrm{Ni}, \mathrm{Pt}, \mathrm{Pd}, \mathrm{Ru}, \mathrm{Rh}$ and Ir. However, there is a serious problem of catalyst deactivation due to rapid coke formation. In addition to carbon deposition, sintering, and/or metal oxidation could be the causes of catalyst deactivation. Different deactivation mechanisms are associated with different catalyst system. For example, in $\mathrm{CO}_{2}$ reforming of $\mathrm{CH}_{4}$ that carbon formation rather than sintering is the main cause of platinum-containing catalyst deactivation.

Precious metals are more coke resistant; however, considering the high cost and limited availability of noble metals, it is more practical in industrial standpoint to develop Ni-based catalysts with high performance and high resistance to carbon deposition. Research on the nickel catalysts used for this reaction has mainly focused on the intrinsic activity of the metal phase, stability toward carbon formation, the type of the support most suitable for improving the efficiency of the catalyst, and the reaction mechanism.

The nature of the support has also significant effects on the performances and properties of catalysts. Supports have many functions but the most important is to maintain a stable physical surface, especially at high reaction temperatures. Therefore, the support itself must resist to thermal transformation at high temperatures, which means catalyst support must have high melting points. It has been proved that type of the support and presence of modifiers greatly affect the coking tendency. The most commonly used support for dry reforming of methane is $\gamma-\mathrm{Al}_{2} \mathrm{O}_{3}$. Other supports such as $\mathrm{MgO}, \mathrm{TiO}_{2}, \mathrm{SiO}_{2}$, and $\mathrm{La}_{2} \mathrm{O}_{3}$ were also used [60] and references therein). Recently, there has been interest in mixed oxides, such as $\mathrm{Ce}_{1-x} \mathrm{Zr}_{x} \mathrm{O}_{2}$ [61], $\mathrm{LaBO}_{3}[62,63](\mathrm{B}=\mathrm{Co}, \mathrm{Ni}, \mathrm{Fe}, \mathrm{Cr})$ and $\mathrm{La}_{2} \mathrm{NiO}_{4}[64$, 65], either as catalysts or catalyst support. $\mathrm{Al}_{2} \mathrm{O}_{3}$ and $\mathrm{SiO}_{2}$ are two of the most often investigated catalyst supports with high specific surface area. $\mathrm{MgO}$ and $\mathrm{CaO}$ are studied due to their high melting points which favor stable catalyst surfaces at high reaction temperatures. Also, their basicity is believed to suppress carbon formation by promoting the activation of $\mathrm{CO}_{2} \cdot \mathrm{TiO}_{2}$ and $\mathrm{ZrO}_{2}$ are reducible metal oxides on which metals are electron-rich and always show strong metal-support interaction (SMSI). SMSI is believed to be critical to resisting carbon formation.

Mesoporous non-crystalline zirconia has shown promising performance as a support for Ni-based catalysts. Long-term stable performance has been achieved even under conditions which favor coke formation and catalysts deactivation [66-69]. 


\section{Oxidative dehydrogenation of hydrocarbons}

This reaction is basically similar to the reactions discussed above and similarly carbon dioxide is not fixed. The product is an olefin and CO. Olefins are highly valued intermediates in petrochemical industry for the production of polymers and fuel additives. The simple dehydrogenation reaction is thermodynamically limited and accompanied by extensive coke formation. $\mathrm{CO}_{2}$ is a coke removing agent as well. Bartholomew [70] reported that oxidizability in the gasification of coke was in the following order: $\mathrm{O}_{2}(105)>\mathrm{H}_{2} \mathrm{O}(3)>\mathrm{CO}_{2}(1)>$ $\mathrm{H}_{2}(0.003)$, where numbers in parenthesis indicated the relative ratios of the gasification with oxidants. $\mathrm{CO}_{2}$ has been called as nontraditional, unusual or mild oxidant and oxygen transfer agent. In this sense, carbon dioxide could be proposed as an oxidant in the oxidative conversions of hydrocarbons.

The promoting effect of $\mathrm{CO}_{2}$ is explained either by hydrogen consumption in the reverse water-gas shift reaction [Eq. (2)], which shifts the equilibrium of, for example, propane dehydrogenation [Eq. (6)] (two-step path) or its participation in direct oxidation of propane to propylene [Eq. (7)] (single-step path). Many studies considered both pathways, especially above $848 \mathrm{~K}\left(575^{\circ} \mathrm{C}\right)$.

$$
\begin{aligned}
& \mathrm{C}_{3} \mathrm{H}_{8} \Leftrightarrow \mathrm{C}_{3} \mathrm{H}_{6}+\mathrm{H}_{2} \quad \Delta H_{298}^{0}=124 \mathrm{~kJ} / \mathrm{mol} \\
& \mathrm{C}_{3} \mathrm{H}_{8}+\mathrm{CO}_{2} \Leftrightarrow \mathrm{C}_{3} \mathrm{H}_{6}+\mathrm{CO}+\mathrm{H}_{2} \mathrm{O} \\
& \Delta H_{298}^{0}=164 \mathrm{~kJ} / \mathrm{mol}
\end{aligned}
$$

The oxide catalysts which are active in the nonoxidative dehydrogenation of propane are also active in the process with $\mathrm{CO}_{2}$. Many bulk and supported oxidebased materials containing active species, such as $\mathrm{Cr}, \mathrm{Ga}$, $\mathrm{Zn}, \mathrm{V}, \mathrm{In}, \mathrm{Fe}$ and $\mathrm{Mn}$ have been studied as catalysts for dehydrogenation of propane in the presence of $\mathrm{CO}_{2}$ [71] and references therein). Among the investigated materials, those containing $\mathrm{Cr}$ or $\mathrm{Ga}$ were found to be the most active and selective one.

The single-step mechanism [direct oxidation of paraffin to olefin, Eq. (7)] has been proposed for redox oxides $\left(\mathrm{Cr}_{2} \mathrm{O}_{3}, \mathrm{Cr}_{2} \mathrm{O}_{5}, \mathrm{ZnO}\right.$ and $\left.\mathrm{V}_{2} \mathrm{O}_{5}\right)$, where $\mathrm{CO}_{2}$ can participate as an oxidizing agent in the following redox cycle [72]:

$\mathrm{C}_{3} \mathrm{H}_{8}+\mathrm{MeO}_{x} \Leftrightarrow \mathrm{C}_{3} \mathrm{H}_{6}+\mathrm{MeO}_{x-1}+\mathrm{H}_{2} \mathrm{O}$

$\mathrm{CO}_{2}+\mathrm{MeO}_{x-1} \Leftrightarrow \mathrm{CO}+\mathrm{MeO}_{x}$

The two-step has been proposed for non-redox oxides such as $\mathrm{Ga}_{2} \mathrm{O}_{3}$ [73]. Production of $\mathrm{H}_{2}$ could be an indication of two-step pathway.

The oxidative dehydrogenation of ethylbenzene to styrene over $\mathrm{Cr}$ or Ce catalysts is one of the most relevant of $\mathrm{CO}_{2}$-assisted reactions [49].

\section{Hydrogenation}

The heterogeneous metal-catalyzed hydrogenation of $\mathrm{CO}_{2}$ goes directly to methanol or methane which is the result of drastic reaction conditions applied in hydrogenations in the presence of heterogeneous catalysts. Formate, formaldehyde, and formyl species, however, have been shown by spectroscopic techniques to exist as surface intermediates during hydrogenation of carbon oxides [57].

Methanol is a versatile multi-source multi-purpose chemical. It could be used as a potentially carbon neutral fuel for automotive and fuel cell application and a feed stock for production of a variety of hydrocarbons including olefins and aromatics [74]. The methanol economy has been a suggested future economy in which methanol replaces fossil fuels as means of energy storage, fuel and raw material for synthetic hydrocarbons and their products [75].

The hydrogenation of $\mathrm{CO}_{2}$ to methanol [Eq. (4)] is interrelated to the hydrogenation of $\mathrm{CO}$ [Eq. (10)] through water-gas shift reaction [Eq. (2)]. A significant disadvantage of $\mathrm{CO}_{2}$ hydrogenation process as compared to the hydrogenation of $\mathrm{CO}$ is that more hydrogen is consumed because of the formation of water.

$$
\mathrm{CO}_{2}+2 \mathrm{H}_{2} \Leftrightarrow \mathrm{CH}_{3} \mathrm{OH} \quad \Delta H_{298}^{0}=-90.8 \mathrm{~kJ} / \mathrm{mol}
$$

It is known through isotope labeling studies that in the hydrogenation of $\mathrm{CO}$ the primary source of methanol is $\mathrm{CO}_{2}$ [57]. It is also known that the traditional threecomponent $\mathrm{Cu}$ catalysts $\left(\mathrm{Cu}-\mathrm{ZnO}-\mathrm{Al}_{2} \mathrm{O}_{3}\right.$ and $\mathrm{Cu}-\mathrm{ZnO}-$ $\mathrm{Cr}_{2} \mathrm{O}_{3}$ ) exhibiting high activity and selectivity in hydrogenation of $\mathrm{CO}$ to methanol show the low activity and selectivity in hydrogenation of pure $\mathrm{CO}_{2}$. Therefore, efforts have been made to find new and more effective catalysts for direct hydrogenation. The problem is to develop catalysts with high selectivity to methanol formation but low selectivity to reverse water-gas shift reaction.

It has been widely reported that $\mathrm{Cu}-\mathrm{ZnO}$-based catalysts with additional oxides are among the most useful systems for catalytic hydrogenation of $\mathrm{CO}_{2}$ to methanol. It has been well documented that the $\mathrm{Cu} / \mathrm{ZnO} / \mathrm{ZrO}_{2}$ catalyst is active in the methanol synthesis from $\mathrm{CO}_{2}$ and $\mathrm{H}_{2}$ [76]. To increase its activity and stability, this basic catalyst was often modified by different oxide additives. Besides $\mathrm{ZrO}_{2}$, other irreducible oxides such as $\mathrm{Al}_{2} \mathrm{O}_{3}, \mathrm{TiO}_{2}$, and $\mathrm{Ga}_{2} \mathrm{O}_{3}$ have been investigated. An example is the high performance multicomponent $\mathrm{Cu}-\mathrm{ZnO}-\mathrm{ZrO}_{2}-\mathrm{Al}_{2} \mathrm{O}_{3}-\mathrm{Ga}_{2} \mathrm{O}_{3}$ catalyst prepared by coprecipitation [77]. The addition of a small amount $(0.6 \mathrm{wt} \%)$ of silica greatly improved the long-term stability of the catalyst [78]. 
As these findings indicate, $\mathrm{ZnO}$ is not an ideal component for $\mathrm{CO}_{2}$ hydrogenation catalysts. As an alternative, a $\mathrm{Cu}-\mathrm{Ga}_{2} \mathrm{O}_{3}$ catalyst was prepared using $\mathrm{ZnO}$ as support, and as support and a silica-supported $\mathrm{Cu}-\mathrm{ZnO}-\mathrm{Ga}_{2} \mathrm{O}_{3}$ sample was also investigated [79]. The latter catalyst exhibited high selectivity to methanol and the conversion to $\mathrm{CO}$ was very low.

Catalysts with metals other than $\mathrm{Cu}$ have also been prepared and used. $\mathrm{Ru}$ on zeolite $\mathrm{NaY}$ prepared by ion exchange and promoted with Co showed high activity for methanol production [80].

Methanation, that is, selective hydrogenation of $\mathrm{CO}_{2}$ to methane [the Sabatier reaction, Eq. (4)], is potentially important transformation, although at present there is no practical reason for producing methane from carbon dioxide and hydrogen. Studies, nevertheless, have been carried out to develop suitable catalysts and find effective reaction conditions. The reaction is highly exothermic and heat removal from the reactor is a major issue.

The full reduction of $\mathrm{CO}_{2}$ into $\mathrm{CH}_{4}$ requires the transfer of eight electrons which leads to significant kinetic limitation. Among all catalysts studied, $\mathrm{Ru}, \mathrm{Rh}$ and $\mathrm{Ni}$ supported on metal oxides exhibit the highest activity, and $\mathrm{Ru}$ has been reported to be the most selective. The supports exert a marked influence of both the adsorption and specific activity of the metals [57]. In most cases, $\mathrm{TiO}_{2}$ is the best support material to achieve good catalyst performance, which attributed to a strong interaction between the metal and the support.

Carbon dioxide usually adsorbs dissociatively on noble metals, and hydrogen facilitates adsorption. On supported $\mathrm{Ru}, \mathrm{Rh}$ and $\mathrm{Pd}$ catalysts, chemisorptions of $\mathrm{CO}_{2}$ in the presence of hydrogen lead to the formation of surface carbonyl hydride [57]. Dissociation of $\mathrm{CO}_{2}$ promoted by hydrogen, the dissociation of surface carbonyl hydride into reactive surface carbon, and hydrogenation of the latter are proposed as important steps in the hydrogenation process.

A related process is the production of ethanol and higher alcohols which have potential as gasoline additives. The reactions are thermodynamically more favorable than hydrogenation of $\mathrm{CO}_{2}$ to methanol. The most successful catalysts are $\mathrm{Rh}$-based, which is prohibitively expensive for large-scale production [81].

\section{Polymerization}

Regarding possible $\mathrm{CO}_{2}$ mitigation by chemical fixation on a large scale, the conversion of carbon dioxide into polymeric and construction materials could be made commercially feasible.

The chemistry of polymerization catalysis is identical, often, to some of the reactions in homogeneous catalysis. Generally, however, the chemistry of copolymerization of
$\mathrm{CO}_{2}$ with organic compounds is not nearly as well developed as homogeneous catalysis. By far, the most common copolymers with $\mathrm{CO}_{2}$ are polycarbonates, which is one of the type of biodegradable polymer [56, 82].

A promising methodology in the utilization of $\mathrm{CO}_{2}$ is its transformation into valuable polycarbonates and/or cyclic carbonates. The synthesis of cyclic carbonates from epoxides and $\mathrm{CO}_{2}$ (Fig. 5) is one of the major ways to transform $\mathrm{CO}_{2}$ to valuable chemicals [51]. The first successful synthesis of cyclic carbonate using room temperature ion in liquids (ILs) of imidazolium and pyridinium salts was reported by Peng and Deng [83]. They found that 1-n-butyl-3-methylimidazolium tetraflouroburate was the most active catalyst with nearly $100 \%$ selectivity, and a suitable $\mathrm{CO}_{2}$-propylene oxide ratio was required for high conversion. The ionic liquid used as the catalyst was recyclable.

Copolymerization of monomers such as azetidines and aziridines with $\mathrm{CO}_{2}$ for poly(urethane)s may lead to new polymers and construction materials for important uses [54]. Bayer announced to plan to market a process to produce polyurethane-based plastics using $\mathrm{CO}_{2}$ as a raw material by 2015 [81] and references therein).

\section{Recent developments and applications}

Processes based on $\mathrm{CO}_{2}$ are known for synthesis of hydrocarbons (via Fischer-Tropsch synthesis), energy-rich $\mathrm{C}_{1}$ molecules $\left(\mathrm{CH}_{4}, \mathrm{CH}_{3} \mathrm{OH}, \mathrm{HCOOH}\right.$, etc. $)$ and fine chemicals containing functionalities such as $-\mathrm{COO}-$ (acids, esters, lactones), -N-COO- (carbamates), or -N-CO(urea, amides) (Cornilis et al. 2003).

As was shown before the major drawback of dry $\mathrm{CO}_{2}$ reforming is the high thermodynamic driving force to produce coke. The SPARG process and the CALCOR process have overcome the coking problem during reforming [81].

The sulfur passivated reforming (SPARG) process was developed to decrease the syngas $\mathrm{H}_{2} / \mathrm{CO}$ ratio from 2.7 obtained from steam reforming to 1.8 without changing the steam reforming facility. Consequently, the SPARG process is suitable as a retrofit to the existing steam reforming plants. Because the use of $\mathrm{CO}_{2}$ instead of steam lowers $\mathrm{H} / \mathrm{C}$ ratios in the product, part of the steam was replaced by $\mathrm{CO}_{2}$. The increased probability of carbon formation and the associated catalyst deactivation is minimized by introducing a partially sulfur-poisoned nickel catalyst. By partially sulfiding of the Ni catalyst, the sites for coke formation are blocked because of ensemble effect while sufficient sites for reforming reaction are maintained [84].

Due to lowering catalyst activity, higher operating temperatures are necessary. The process operates at 1,188-1,218 $\mathrm{K}$ which decreases the $\mathrm{CH}_{4}$ slip but the 
Fig. 5 Coupling of $\mathrm{CO}_{2}$ and epoxides to afford polycarbonates and/or cyclic carbonates

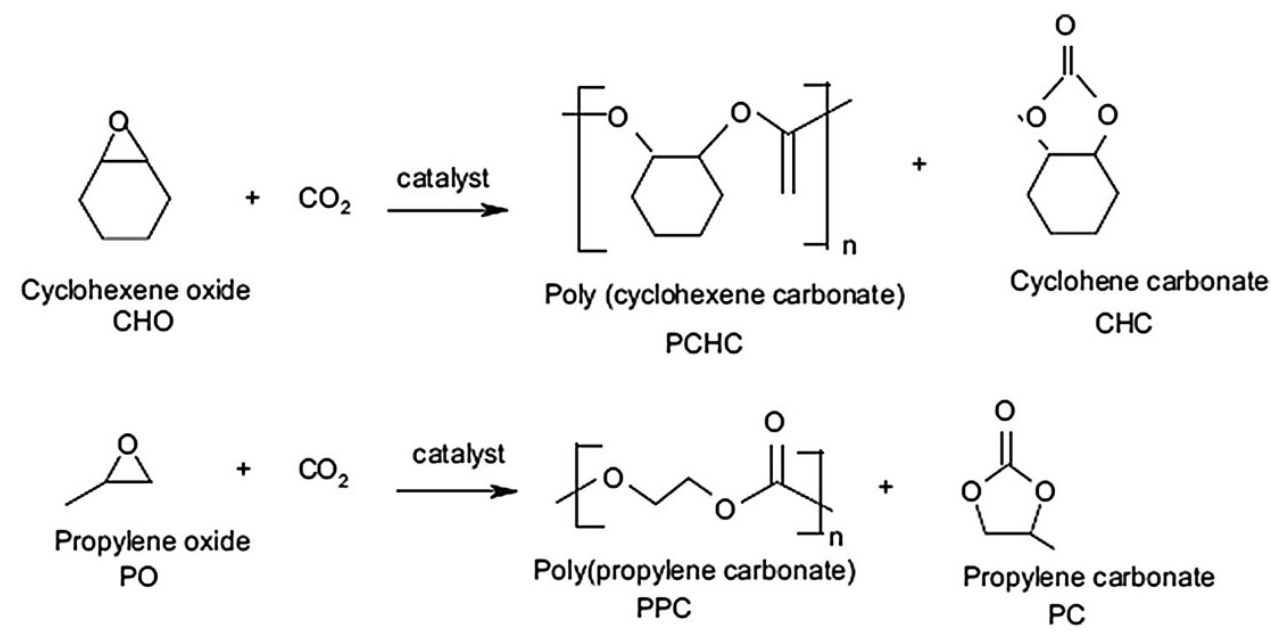

$\mathrm{CO}_{2}$ and steam reforming from natural gas. It is a synergic combination of endothermic $\mathrm{CO}_{2}$ and steam reforming and exothermic partial oxidation of $\mathrm{CH}_{4} \cdot \mathrm{CO}_{2}$ from flue gas does not need to be separated. In fact, $\mathrm{H}_{2}, \mathrm{O}_{2}$ and $\mathrm{CO}_{2}$ in waste flue gas from fossil fuel power plants will be used to tri-reforming natural gas and produce syngas.

Tri-reforming does have a different requirement on the catalyst composition to dry and steam reforming. It can be performed with stable operation and no carbon formation and no appreciable deactivation of tri-forming conditions. $\mathrm{Pt} / \mathrm{ZrO}_{2}$ and $\mathrm{Ni} / \mathrm{ZrO}_{2}$ showed high activity for steam and dry reforming and partial oxidation of methane [86]. $\mathrm{Ni}$ on $\mathrm{ZrO}_{2}$ and $\mathrm{ZrO}_{2}$ doped with yttrium and a lanthanide and alkaline earth metal has been patented for this process [87].

In the CAMERE (carbon dioxide hydrogenation to form methanol via a reverse water-gas-shift reaction) of Korean Institute of Science and Technology, $\mathrm{CO}_{2}$ is converted to methanol [58]. In CAMERE process, carbon dioxide and hydrogen are converted to $\mathrm{CO}$ and $\mathrm{H}_{2} \mathrm{O}$ by RWGS reaction over a $\mathrm{ZnAl}_{2} \mathrm{O}_{4}$ catalyst in a separate reactor and then the gas mixture is fed into a methanol synthesis reactor after water has been removed.

A commercial plant constructed by Carbon Recycling International (CRI) company for $\mathrm{CO}_{2}$ hydrogenation to methanol is currently operative in Iceland using geothermal energy source $[81,88]$. Recently in Japan, the construction of a 100 tpy demonstration plant for single-step production of methanol from $\mathrm{CO}_{2}$ was announced [89]. The $\mathrm{CO}_{2}$ feed comes as a byproduct of Mitsui Chemical Complex at Osaka and $\mathrm{H}_{2}$ from water using renewable (solar) energy [90].

Many petrochemical and licensing companies are working on carbon dioxide capture and use to achieve sustainability in the petrochemical industry. As reported by Reuters on Jan 14, 2014, SABIC and KACST are examples in the Middle East. Several projects at KACST contribute to the sustainability development in the petrochemical 
sector. Examples include power generation with available fuels at well heads with $\mathrm{CO}_{2}$ capture and use for enhance oil recovery (EOR), $\mathrm{CO}_{2}$ utilization to produce syngas (dry reforming project) and utilizing carbon dioxide as regenerative agent to increase the commercial potential of methane dry reforming.

Saudi Basic Industries Corp (SABIC) has hired Germany's Linde Group to build the world's largest plant for capturing and using climate-warming carbon dioxide. The United Jubail Petrochemical Company, an affiliate of SABIC, plans to capture around 1,500 tons a day of carbon dioxide from ethylene plants and purify it for use in SABIC-owned petrochemical plants in the industrial city of Jubail. The high cost of catching gas emitted by factories and power plants and storing it safely underground have deterred commercial CCS projects.

Mitsubishi Heavy Industries, Ltd. (MHI) has signed a license agreement for carbon dioxide $\left(\mathrm{CO}_{2}\right)$ recovery technology with Gulf Petrochemical Industries Company (GPIC), a manufacturer of fertilizers and petrochemicals in Bahrain. GPIC will use the technology to recover $\mathrm{CO}_{2}$ from flue gas emitted at its existing petrochemical plant and utilize the captured $\mathrm{CO}_{2}$ to increase urea and methanol production. The recovery units can capture 450 metric tons of $\mathrm{CO}_{2}$ per day, one of the world's largest capacities for the chemical application. In addition to urea production, $\mathrm{CO}_{2}$ recovery technology can be used in chemical applications such as production of methanol and dimethyl ether (DME) and, in the food and beverage industries, production of carbonated beverages and dry ice. Another important possible application is enhanced oil recovery (EOR) enabling increased crude oil production; in this case, $\mathrm{CO}_{2}$ is injected into an oil reservoir suffering from low productivity [91].

\section{Conclusions}

There are many potential options for carbon dioxide capture from petrochemical industry and its utilization as a $\mathrm{C}_{1}$ feedstock for the production of petrochemical intermediates and/or products. However, as the capture and the transformation of $\mathrm{CO}_{2}$ by itself requires energy input and $\mathrm{CO}_{2}$ gives no enthalpy contribution to the final product, the contribution to net $\mathrm{CO}_{2}$ emission could not be significant unless more effective techniques and renewable energy (or hydrogen) source are available. Consequently, the product demand, the source of energy and overall net carbon emissions have to be taken into consideration. Large impact of carbon dioxide capture and fixation on global $\mathrm{CO}_{2}$ emissions could be realized only if bulk chemicals are the target of conversion. Several potential utilization routes are possible for the petrochemical industry. Based on the above discussions on $\mathrm{CO}_{2}$ separation methods, it can be concluded that flue gases properties (mainly concentration of $\mathrm{CO}_{2}$, temperature and pressure) are the most effective factors for selection of suitable process for $\mathrm{CO}_{2}$ separation. Catalytic $\mathrm{CO}_{2}$ hydrogenation seems to have the highest potential for implementation in petrochemical industry. Further R\&D is needed on catalysis and hydrogen (energy) source. Electrochemical or photo-electrochemical $\mathrm{CO}_{2}$ conversion is promising, but technology is still in its infancy.

Open Access This article is distributed under the terms of the Creative Commons Attribution License which permits any use, distribution, and reproduction in any medium, provided the original author(s) and the source are credited.

\section{References}

1. United Nations Framework Convention on Climate Change (UNFCCC). http://unfccc.int/ghg_data/ghg_data_unfccc/ghg_ profiles/items/4625.php. Accessed January 2014

2. Sahebdelfar S, Tahriri Zangeneh F, Takht Ravanchi M (2009) Chemical recycling of carbon dioxide to valuable petrochemicals. In: The 7th APCSEET conference, Qingdao, China

3. Takht Ravanchi M, Sahebdelfar S, Tahriri Zangeneh F (2009a) Carbon dioxide sequestration in petrochemical industries with the aim of reduction in greenhouse gas emissions. In: The 7th APCSEET conference, Qingdao, China

4. Seddon D (2010) Petrochemical economics technology selection in a carbon constrained world. Imperial College, London

5. Granite EJ, O'Brien T (2005) Review of novel methods for carbon dioxide separation from flue and fuel gases. Fuel Proc Technol 86:1423-1434

6. Stewart C, Hessami MA (2005) A study of methods of carbon dioxide capture and sequestration-the sustainability of a photosynthetic bioreactor approach. Energ Convers Manage 46:403-420

7. Olajire AA (2010) $\mathrm{CO}_{2}$ capture and separation technologies for end-of-pipe applications-—a review. Energy 35:2610-2628

8. Pires JCM, Martins FG, Alvim-Ferraz MCM, Simes M (2011) Recent developments on carbon capture and storage: an overview. Chem Eng Res Des 89:1446-1460

9. Takht Ravanchi M, Sahebdelfar S, Tahriri Zangeneh F (2011) Carbon dioxide sequestration in petrochemical industries with the aim of reduction in greenhouse gas emissions. Front Chem Sci Eng 5:173-178

10. Wang M, Lawal A, Stephenson P, Sidders J, Ramshaw C (2011) Post-combustion $\mathrm{CO}_{2}$ capture with chemical absorption: a stateof-the-art review. Chem Eng Res Des 89:1609-1624

11. Kargari A, Takht Ravanchi M (2012) Carbon dioxide: capturing and utilization. In: Liu G (ed) Greenhouse Gases INTECH, pp $1-30$

12. Zhao B, Su Y, Tao W, Li L, Peng Y (2012) Post-combustion $\mathrm{CO}_{2}$ capture by aqueous ammonia: a state-of-the-art review. Int $\mathrm{J}$ Greenh Gas Control 9:355-371

13. Songolzadeh M, Soleimani M, Takht Ravanchi M, Songolzadeh $\mathrm{R}$ (2014) Carbon dioxide separation from flue gases; a technological review emphasizing on reduction in greenhouse gas emissions. Sci World J. doi:10.1155/2014/828131

14. Wang Sh, Zhu ZH (2004) Catalytic conversion of alkanes to olefins by carbon dioxide oxidative dehydrogenation-a review. Energ Fuel 18:1126-1139

15. Song Ch (2006) Global challenges and strategies for control, conversion and utilization of $\mathrm{CO}_{2}$ for sustainable development 
involving energy, catalysis, adsorption and chemical processing. Catal Today 115:2-32

16. He LN, Wang JQ, Wang JL (2009) Carbon dioxide chemistry: examples and challenges in chemical utilization of carbon dioxide. Pure Appl Chem 81:2069-2080

17. Havran V, Dudukovic MP, Lo CS (2011) Conversion of methane and carbon dioxide to higher value products. Ind Eng Chem Res 50:7089-7100

18. Skjånes K, Lindblad $\mathrm{P}$, Muller $\mathrm{J}$ (2007) $\mathrm{BioCO}_{2}$-a multidisciplinary, biological approach using solar energy to capture $\mathrm{CO}_{2}$ while producing $\mathrm{H}_{2}$ and high value products. Biomol Eng 24:405-413

19. Richter HJ, Knoche K (1983) Reversibility of combustion processes, efficiency and costing- second law analysis of processes. ACS Symp Ser 235:71-85

20. Davidson RM (2007) Post-combustion carbon capture from coal fired plants-solvent scrubbing. IEA Clean Coal Centre, CCC/ 125

21. Alie C, Backham L, Croiset E, Douglas PL (2005) Simulation of $\mathrm{CO}_{2}$ capture using MEA scrubbing: a flowsheet decomposition method. Energy Conv Manag 46:475-487

22. Mamun S, Svendsen HF, Haff KA, Juliussen O (2007) Selection of new absorbents for carbon dioxide capture. Energy Conver Manage 48:251-258

23. Darde V, Thomsen K, van Well WJM, Stenby EH (2010) Chilled ammonia process for $\mathrm{CO}_{2}$ capture. Int $\mathrm{J}$ Greenh Gas Control 4:131-136

24. Cullinane JT, Rochelle GT (2005) Thermodynamics of aqueous potassium carbonate, piperazine, and carbon dioxide. Fluid Phase Equilib 227:197-213

25. Freeman SA, Dugas R, Van Wagener DH, Nguyen T, Rochelle GT (2010) Carbon dioxide capture with concentrated, aqueous piperazine. Int J Greenh Gas Control 4:119-124

26. Kovvali AS, Sirkar KK (2002) Carbon dioxide separation with novel solvents as liquid membranes. Ind Eng Chem Res 41:2287-2295

27. Takht Ravanchi M, Kaghazchi T, Kargari A (2009) Application of membrane separation processes in petrochemical industry: a review. Desal 235:199-244

28. Chow JC, Watson JG, Herzog A, Benson SM, Hidy GM, Gunter WD, Penkala SJ, White CM (2003) Critical review discussionseparation and capture of $\mathrm{CO}_{2}$ from large stationary sources and sequestration in geological formations. J Air Waste Manage Assoc 53:1172-1182

29. White CM, Strazisar BR, Granite EJ, Hoffman JS, Pennline HW (2003) Separation and capture of $\mathrm{CO}_{2}$ from large stationary sources and sequestration in geological formations-coal beds and deep saline aquifers. J Air Waste Manage Assoc 53:645-715

30. Bounaceur R, Lape N, Roizard D, Vallieres C, Favre E (2006) Membrane processes for post-combustion carbon dioxide capture: a parametric study. Energy 31:2556-2570

31. Scholes CA, Kentish SE, Stevens GW (2009) The effect of condensable minor components on the gas separation performance of polymeric membranes for carbon dioxide capture. Energy Procedia 1:311-317

32. Xomeritakis G, Tsai CY, Jiang YB, Brinker CJ (2009) Tubular ceramic-supported sol-gel silica-based membranes for flue gas carbon dioxide capture and sequestration. J Membr Sci 341:30-36

33. Drage TC, Smith KM, Pevida C, Arenillas A, Snape CE (2009) Development of adsorbent technologies for post-combustion $\mathrm{CO}_{2}$ capture. Energy Procedia 1:881-884

34. Thiruvenkatachari R, Su S, An H, Yu XX (2009) Post combustion $\mathrm{CO}_{2}$ capture by carbon fibre monolithic adsorbents. Prog Energ Combust 35:438-455
35. An H, Feng B, Su S (2009) $\mathrm{CO}_{2}$ capture capacities of activated carbon fibre-phenolic resin composites. Carbon 47:2396-2405

36. Pevida C, Snape CE, Drage TC (2009) Templated polymeric materials as adsorbents for the postcombustion capture of $\mathrm{CO}_{2}$. Energy Procedia 1:869-874

37. Chatti R, Bansiwal AK, Thote JA, Kumar V, Jadhav P, Lokhande SK, Biniwale RB, Labhsetwar NK, Rayalu SS (2009) Amine loaded zeolites for carbon dioxide capture: amine loading and adsorption studies. Micropor Mesopor Mater 121:84-89

38. Yadav VS, Prasad M, Khan J, Amritphale SS, Singh M, Raju CB (2010) Sequestration of carbon dioxide $\left(\mathrm{CO}_{2}\right)$ using red mud. J Hazard Mater 176:1044-1050

39. Maroto-Valer MM, Tang Z, Zhang Y (2005) $\mathrm{CO}_{2}$ capture by activated and impregnated anthracites. Fuel Process Technol 86:1487-1502

40. Pevida C, Plaza MG, Arias B, Fermoso J, Rubiera F, Pis JJ (2008) Surface modification of activated carbons for $\mathrm{CO}_{2}$ capture. Appl Surf Sci 254:7165-7172

41. Fauth DJ, Frommell EA, Hoffman JS, Reasbeck RP, Pennline HW (2005) Eutectic salt promoted lithium zirconate: novel high temperature sorbent for $\mathrm{CO}_{2}$ capture. Fuel Process Technol 86:1503-1521

42. Essaki $\mathrm{K}$, Nakagawa $\mathrm{K}$, Kato $\mathrm{M}$, Uemoto $\mathrm{H}$ (2004) $\mathrm{CO}_{2}$ absorption by lithium silicate at room temperature. J Chem Eng Jpn 37:772-777

43. Kato M, Nakagawa K, Essaki K, Maezawa Y, Takeda S, Kogo R (2005) Novel $\mathrm{CO}_{2}$ absorbents using lithium-containing oxide. Int J Appl Ceramic Technol 2:467-475

44. Zhao Z, Cui X, Ma J, Li R (2007) Adsorption of carbon dioxide on alkali-modified zeolite $13 \times$ adsorbents. Int $\mathrm{J}$ Greenh Gas Control 1:355-359

45. Drage TC, Arenillas A, Smith KM, Pevida C, Piippo S, Snape CE (2007) Preparation of carbon dioxide adsorbents from the chemical activation of urea-formaldehyde and melamine-formaldehyde resins. Fuel 86:22-31

46. Singh R, Reddy MKR, Wilson S, Joshi K, Diniz da Costa JC, Webley P (2009) High temperature materials for $\mathrm{CO}_{2}$ capture. Energy Procedia 1:623-630

47. Sjostrom S, Krutka H (2010) Evaluation of solid sorbents as a retrofit technology for $\mathrm{CO}_{2}$ capture. Fuel 89:1298-1306

48. Ho MT, Allinson GW, Wiley DE (2008) Reducing the cost of $\mathrm{CO}_{2}$ capture from flue gases using pressure swing adsorption. Ind Eng Chem Res 47:4883-4890

49. Cornils B, Herrmann WA, Schlogl R, Wong C-H (2003) Catalysis from A to Z: A Concise Encyclopedia. Wiley, Weinheim

50. Hua B, Guild C, Suib SL (2013) Thermal, electrochemical, and photochemical conversion of $\mathrm{CO}_{2}$ to fuels and value-added products. $\mathrm{J} \mathrm{CO}_{2}$ Util 1:18-27

51. Olajire AA (2013) Valorization of greenhouse carbon dioxide emissions into value-added products by catalytic processes. $\mathrm{J} \mathrm{CO}_{2}$ Util 3-4:74-92

52. Sakakura T, Choi J-C, Yasuda H (2007) Transformation of carbon dioxide. Chem Rev 107:2365-2387

53. Tahriri Zangeneh F, Sahebdelfar S, Takht Ravanchi M (2011) Conversion of carbon dioxide to valuable petrochemicals: an approach to clean development mechanism. J Nat Gas Chem 20:219-231

54. Yu KMK, Curcic I, Gabriel J, Tsang SCE (2008) Recent advances in $\mathrm{CO}_{2}$ capture and utilization. ChemSusChem 1:893-899

55. Aresta M, Dibenedetto A, Angelini A (2013) The changing paradigm in $\mathrm{CO}_{2}$ utilization. $\mathrm{J} \mathrm{CO}$ Util 3-4:65-73

56. Heyn RH (2003) Carbon dioxide conversion. In: Horvath IT (ed) Encyclopedia of catalysis. Wiley, New Jersey, pp 19-71

57. Olah GA, Molnar A (2003) Hydrocarbon chemistry. Wiley, New Jersey 
58. Park SW, Joo OS, Jung KD, Kim H, Han SH (2000) $\mathrm{ZrO}_{2} / \mathrm{Cr}_{2} \mathrm{O}_{3}$ catalyst for reverse-water-gas-shift reaction of CAMERE process. Korean J Chem Eng 17:719-722

59. Joo O-S, Jung K-D (2003) Stability of $\mathrm{ZnAl}_{2} \mathrm{O}_{4}$ catalyst for reverse-water-gas-shift reaction (RWGSR). Bull Korean Chem Soc 24:86-90

60. Guo J, Lou H, Zhao H, Chai D, Zheng X (2004) Dry reforming of methane over nickel catalysts supported on magnesium aluminate spinels. Appl Catal A Gen 273:75-82

61. Montoya JA, Romero-Pascual E, Gimon C, Del Angel P, Monzon A (2000) Methane reforming with $\mathrm{CO}_{2}$ over $\mathrm{Ni} / \mathrm{ZrO}_{2}-\mathrm{CeO}_{2}$ catalysts prepared by sol-gel. Catal Today 63:71-85

62. Guo JJ, Lou H, Zhu YH, Zheng XM (2003) $\mathrm{CO}_{2}$ reforming of $\mathrm{CH}_{4}$ over nickel and cobalt catalysts prepared from La-based perovskite precursors. J Nat Gas Chem 12:17-22

63. Wu YY, Kawaguchi O, Matsuda T (1998) Catalytic reforming of methane with carbon dioxide on $\mathrm{LaBO}_{3}(\mathrm{~B}=\mathrm{Co}, \mathrm{Ni}, \mathrm{Fe}, \mathrm{Cr})$ catalysts. Bull Chem Soc Jpn 71:563-572

64. Guo JJ, Lou H, Zhu YH, Zheng XM (2003) La-based perovskite preparations, properties, and its catalytic action for $\mathrm{CO}_{2}$ reforming of $\mathrm{CH}_{4}$. Mater Lett 57:4450-4456

65. Nam JW, Chae H, Lee SH, Jung H, Lee KY (1998) Natural gas conversion. Stud Surf Sci Catal 119:843-847

66. Rezaei M, Alavi SM, Sahebdelfar S, Yan ZF (2006) Nanocrystalline zirconia as support for nickel catalyst in methane reforming with $\mathrm{CO}_{2}$. Energy Fuels 20:923-929

67. Rezaei M, Alavi SM, Sahebdelfar S, Liu XM, Qian L, Yan ZF (2007) $\mathrm{CO}_{2}-\mathrm{CH}_{4}$ reforming over nickel catalysts supported on mesoporous nanocrystalline zirconia with high surface area. Energy Fuels 21:581-589

68. Rezaei M, Alavi SM, Sahebdelfar S, Yan ZF (2008) Effect of $\mathrm{CO}_{2}$ concentration on the activity and stability of nickel catalyst supported on mesoporous nanocrystalline zirconia. J Nat Gas Chem 17:278-288

69. Rezaei M, Alavi SM, Sahebdelfar S, Yan ZF (2009) A highly stable catalyst in methane reforming with carbon dioxide. Scripta Mater 61:173-176

70. Bartholomew CH (1984) Catalyst deactivation. Chem Eng 91:96-112

71. Michorczyk P, Ogonowski J, Zenczak K (2011) Activity of chromium oxide deposited on different silica supports in the dehydrogenation of propane with $\mathrm{CO}_{2}$ - a comparative study. J Mol Catal A Chem 349:1-12

72. Michorczyk P, Ogonowski J, Kustrowski P, Chmielarz L (2008) Chromium oxide supported on MCM-41 as a highly active and selective catalyst for dehydrogenation of propane with $\mathrm{CO}_{2}$. Appl Catal A Gen 349:62-69

73. Xu B, Zheng B, Hua W, Yue Y, Gao Z (2006) Support effect in dehydrogenation of propane in the presence of $\mathrm{CO}_{2}$ over supported gallium oxide catalysts. J Catal 239:470-477

74. Olah GA (2005) Beyond oil and gas: the methanol economy. Angew Chem Int Ed 44:2636-2639
75. Olah GA, Goeppert A, Prakash GKS (2006) Beyond oil and gas: the methanol economy. Wiley-VCH, Weinheim

76. Słoczynski J, Grabowski R, Olszewski P, Kozłowska A, Stoch J, Lachowska M, Skrzypek J (2006) Effect of metal oxide additives on the activity and stability of $\mathrm{Cu} / \mathrm{ZnO} / \mathrm{ZrO}_{2}$ catalysts in the synthesis of methanol from $\mathrm{CO}_{2}$ and $\mathrm{H}_{2}$. App Catal A Gen 310:127-137

77. Saito M, Fujitani T, Takeuchi M, Watanabe T (1996) Development of copper/zinc oxide-based multicomponent catalysts for methanol synthesis from carbon dioxide and hydrogen. Appl Catal A 138:311-318

78. Saito M, Takeuchi M, Fujitani T, Toyir J, Lou S, Wu J, Mabuse H, Ushikoshi K, Mori K, Watanabe T (2000) Advances in joint research between NIRE and RITE for developing a novel technology for methanol synthesis from $\mathrm{CO}_{2}$ and $\mathrm{H}_{2}$. Appl Organomet Chem 14:763-772

79. Toyir J, de la Piscina RR, Fierro JLG, Homs N (2001) Highly effective conversion of $\mathrm{CO}_{2}$ to methanol over supported and promoted copper-based catalyst: influence of support and promoter. App Catal B 29:207-215

80. Bando KK, Arakawa $\mathrm{H}$, Ichikuni N (1999) $\mathrm{CO}_{2}$ hydrogenation over micro- and mesoporous oxides supported catalysts. Catal Lett 60:125-132

81. Homs N, Toyir J, de la Piscia PR (2013) Catalytic processes for activation of $\mathrm{CO}_{2}$. In: Suib SL (ed) New and future developments in catalysis: activation of carbon dioxide, 1st edn. Elsevier, Amsterdam, pp 1-23

82. Miao CX, Wang JQ, He LN (2008) Catalytic processes for chemical conversion of carbon dioxide into cyclic carbonates and polycarbonates. Open Organic Chem J 2:68-82

83. Peng JJ, Deng YQ (2001) Cycloaddition of carbon dioxide to propylene oxide by ionic liquids. New J Chem 25:639-641

84. Verykios XE (2003) Catalytic dry reforming of natural gas for production of chemicals and hydrogen. Int $\mathrm{J}$ Hydrog Energy 28:1045-1063

85. Teuner STC, Neuman P, Linde FV (2001) The calcor standard and calcor economy processes. Oil Gas Euro Mag 3:44-46

86. Hegarty HES, Ross JRH, O'Conner AM (1998) Syngas production from natural gas using $\mathrm{ZrO}_{2}$-supported metals. Catal Today 42:225-232

87. Moon DJ, Kang JS, Nho WS, Kim DH, Lee SD, Lee BG (2008) Ni-based catalyst for tri-reforming of methane and its catalytic application for the production of syngas. US 20080260628 A

88. Shulenberger AM, Jonsson FR, Ingolfsson O, Tran KC (2007) US patent application $0244208 \mathrm{~A} 1$

89. Trembaly JF (2008) $\mathrm{CO}_{2}$ as a feedstock, Mitsui will make methanol from greenhouse gas. Chem Eng News 86:13

90. Olah GA, Goeppert Prakash GKS (2009) Chemical recycling of carbon dioxide to methanol and dimethyl ether: from Greenhouse Gas to renewable environmentally carbon neutral and synthetic hydrocarbons. J Org Chem 74:487-498

91. Bahrain: Betting on Industry. http://www.bahiw.com/pdf/ ecnomicmarch0109.pdf. Accessed January 2014 